\title{
Nutrient composition and in vitro digestion parameters of Jerusalem artichoke (Helianthus tuberosus L.) herbage at different maturity stages in horse and ruminant
}

\author{
A.C. Ersahince and K. Kara ${ }^{1}$ \\ Erciyes University, Faculty of Veterinary Medicine, Department of Animal Nutrition and Nutritional Diseases \\ 38280 Kayseri, Turkey
}

KEY WORDS: horses, ruminants, carotenoids, herbage, Jerusalem artichoke, maturity stage, in vitro digestion

Received: 25 November 2016

Revised: $\quad 19$ June 2017

Accepted: 8 September 2017
${ }^{1}$ Corresponding author:

e-mail: kanberkara@erciyes.edu.tr

\begin{abstract}
The aim of the study was to determine the nutrient composition and in vitro digestion parameters of Jerusalem artichoke (Helianthus tuberosus L.) herbage at different maturity stages (vegetative, early flowering, full flowering and early seeding) in horses and ruminants. The crude protein (CP), ether extract (EE), ash, non-fibrous carbohydrate (NFC), neutral detergent fibre assayed with a heat stable amylase and expressed exclusive of residual ash (aNDFom), acid detergent fibre expressed exclusive of residual ash (ADFom), acid detergent lignin (ADL), total condensed tannins (TCT), total saponin (TSP) and carotenoids (lutein, zeaxanthin, lycopene and $a-, \beta-, y$-carotenes) content in plant samples were analysed. The in vitro total gas and methane production, metabolizable energy (ME), true dry matter disappearance (T-DMd), true organic matter disappearance (T-OMd), gas yield $\left(\mathrm{GY}_{24}\right)$, partial factor $\left(\mathrm{PF}_{24}\right)$ and microbial crude protein production (MCP) values and volatile fatty acids (VFAs) concentration in fermentation fluid for herbage samples were determined with the in vitro digestion techniques carried out using horse faeces and ruminant fluids. The aNDFom, ADFom, ADL, EE and TCT content increased with plant maturation $(P<0.05)$. Zeaxanthin, lycopene and $\beta$-carotene content was the highest in full flowering and the lowest in early seeding plant $(P<0.05)$. With the plant maturation the following parameters decreased $(P<0.05)$ : CP, NFC, ash and TSP content in plant samples, and in vitro total gas and methane production, T-DMd, T-OMd, ME values and molarities of individual VFAs for both horses and ruminants. Consequently, Jerusalem artichoke herbage, especially at vegetative stage, has the potential to be used as quality forage in terms of high/moderate nutrient composition and satisfactory digestion values for both horses and ruminants.
\end{abstract}

\section{Introduction}

Jerusalem artichoke (Helianthus tuberosus L.) is a tuberous plant belonging to Asteraceae family and originating from North America that can be cultivated in various areas of the world (Gunnarsson et al., 2014). It is a $3-4 \mathrm{~m}$ long perennial plant. Its length, colour of tubers, numbers of branches and stems, and leaf ratio are dependent on variety, soil type and climatic conditions (Kays and Nottingham, 2007; Szpunar-Krok et al., 2016). It can be cultivated on various soil types ( $\mathrm{pH} 4.5-8.2$ and salinity) and different climatic conditions (in average $6.3-26.6{ }^{\circ} \mathrm{C}$ ). In the leaves there are natural substances like $\beta$-bisabolene, 
$\alpha$-copaene, caryophyllene oxide and neophytadiene (Helmi et al., 2014; Yang et al., 2015; Szpunar-Krok et al., 2016).

Jerusalem artichoke has a number of advantages: low input cultivation, high crop yield and strong resistance to pests and plant diseases (Yang et al., 2015). It was demonstrated that some bioactive compounds (such as sesquiterpene lactones) present in its leaves have antimicrobial effects. The Jerusalem artichoke tuber or tuber meal is commonly used in animal and human nutrition as inulin source (Helmi et al., 2014). Its areal parts (leaf, stem) were used in domestic animal nutrition in the previous century (Konopiński and Bormann, 1937; Becker and Nehring, 1969), and forgotten for many years now are again investigated in herbivore nutrition (Razmkhah et al., 2017). It is known that areal parts of Jerusalem artichoke include $35-37 \%$ neutral detergent fibre assayed with a heat stable amylase and expressed exclusive of residual ash (aNDFom), 24-25\% acid detergent fibre expressed exclusive of residual ash (ADFom), 37-41\% nonfibrous carbohydrate (NFC) and about $18 \%$ crude protein (CP) (Stauffer et al., 1980; Karsli and Bingöl, 2009); in ruminants the in vitro organic matter digestibility (OMD) and metabolizable energy (ME) value of these green mass ranged from 59 to $63 \%$ and about $9.6 \mathrm{MJ} \cdot \mathrm{kg}^{-1}$, respectively (Karsli and Bingöl, 2009). These features make the Jerusalem artichoke a good forage for herbivores perfectly digesting fibre like ruminants and horses. However, it contains antinutritional components as saponins and tannins which at high concentration can cause some negative effects on animals.

Grazing herbivores are characterized by a great variety of mechanisms and anatomical formations that use the chemical energy locked up in the plant structural carbohydrates (aNDFom, ADFom). Some parts of the gastrointestinal tract in these animals are bigger than in others in order to accommodate the fermented forage digested by microorganisms producing volatile fatty acids (VFAs) and lactate (Allen, 1997; Frape, 2004). The most important sections were fibre, i.e. cellulose, hemicellulose and lignin, is digested are caecum and ventral colon (in horses) and rumen (in ruminants) (NRC, 2001; Frape, 2004). Dietary fibre stimulates chewing activity and saliva flow to the rumen in ruminants. Bicarbonate and phosphate buffers in saliva neutralize acidity increased by fermentation of organic matter in the rumen. Inadequacy of fibre or forage in ruminant diet may decrease the chewing movements, ruminal $\mathrm{pH}$, fibre digestibility, microbial yield, and lead to metabolic disorders like acidosis, laminitis, displaced abomasum (Shaver, 1997; NRC, 2001). Similarly, fibrous feeds in horse diet are important for intestinal peristalsis, chewing movements, hindgut volume and fluid/electrolyte retention, and they prevent some metabolic upsets glycaemic disorders, metabolic acidosis and laminitis (Frape, 2004). Besides the fact that such forages have beneficial effects on digestion in horses and ruminants, they may be also a source of protein, soluble carbohydrate, energy and carotenoids.

Nowadays, the countries in the southern parts of Europe and in the Eastern Mediterranean region cope with changing climate conditions. The increased temperature makes the production of forage plants more difficult. Therefore, studies on the alternative forage sources, which are suitable for arid and semi-arid climatic conditions, have been intensified (Kara et al., 2015, 2016).

The aim of the present study was to determine the nutrient composition and in vitro digestion values of Jerusalem artichoke (Helianthus tuberosus L.) herbage in two herbivores - horses and ruminants whose diet is characterised by high forage:concentrate ratio. In the study, Jerusalem artichoke herbage was harvested at different maturity stages in Central Anatolia (Turkey) where arid climatic conditions are dominant. Thus, it was hypothesized that Jerusalem artichoke herbage can be used as an alternative forage source.

\section{Material and methods}

\section{Samples collection area}

Plant samples were collected in Karaman, Central Anatolia region (Turkey), $1038 \mathrm{~m}$ a.s.1. $\left(36^{\circ} 33^{\prime} 50^{\prime \prime} \mathrm{N}, 32^{\circ} 56^{\prime} 52^{\prime \prime} \mathrm{E}\right)$ where steppe and dry forests dominate. The mean January temperature is $0{ }^{\circ} \mathrm{C}$ and in July - above $20^{\circ} \mathrm{C}$. The mean annual rainfall amount is below $400 \mathrm{~mm}$. Rain type is convectional and frontal. These features are typical for arid conditions (Altın et al., 2012).

\section{Plant samples}

Plant samples were harvested in the morning, above $5 \mathrm{~cm}$ from the soil, at four different maturity stages: vegetative (June 2015) $(n=6)$, early flowering (July 2015) $(n=6)$, full flowering (August 2015) $(n=6)$, and early seeding (September 2015) $(n=6)$ (Table 1). For each maturity stage, six different plants were collected with all the aerial parts (leaf, stem and flower). 
Table 1. Maturity stages of Jerusalem artichoke herbage

\begin{tabular}{ll}
\hline Maturity stages & $\begin{array}{c}\text { Stage definition } \\
\text { Vegetative }\end{array}$ \\
$\begin{array}{c}\text { Stem length }<100 \mathrm{~cm} \text {; no buds or flowers; } \\
\text { green leaves }\end{array}$ \\
Early flowering & $\begin{array}{c}\text { Stem length }>100 \mathrm{~cm} \text {; start of flowering } \\
\text { (yellow colour); green leaves }\end{array}$ \\
Full flowering & $\begin{array}{c}\text { Open flowers (yellow colour); green leaves } \\
\text { Early seeding }\end{array} \quad \begin{array}{c}\text { Brown and dried flowers; first green pods; } \\
\text { green leaves; leaves, near the ground starting to dry }\end{array}$ \\
\hline
\end{tabular}

\section{Chemical analysis}

The plants were dried in a thermostatically controlled cabinet (Lovidond, Dortmund, Germany) at $55{ }^{\circ} \mathrm{C}$ for $48 \mathrm{~h}$. After drying, the samples were milled through a $1 \mathrm{~mm}$ sieve (IKA Werke, Staufen im Breisgau, Germany). The ash content was estimated by igniting the samples in a muffle furnace at $525{ }^{\circ} \mathrm{C}$ for $8 \mathrm{~h}$ (AOAC, 1990; method 942.05). Nitrogen (N) content was measured by the Kjeldahl method (DK6 Kjeldahl Digestion Unit, Velp Scientifica, Usmate, Italy) and crude protein $(\mathrm{CP})$ was calculated as $\mathrm{N} \times 6.25$ (AOAC, 1990; method 942.01). The ether extract (EE) level was determined according to the AOAC (1990; method 920.39) with the use of a solvent extractor (SER 148/3, Velp Scientifica, Usmate, Italy). The neutral detergent fibre (NDF), acid detergent fibre (ADF) and acid detergent lignin (ADL) content were analysed using a fibre analyser (FIWE3 Fibre Analyzer, Velp Scientifica, Usmate Italy) according to the methods reported by Van Soest et al. (1991). The aNDF was determined using sodium sulphite $(0.5 \mathrm{~g})$ and thermo-stable $\alpha$-amylase $(100 \mu 1)$ (Megazyme, Irishtown, Bray, Co. Wicklow, Ireland). The aNDF, $\mathrm{ADF}$ and $\mathrm{ADL}$ contents were corrected for ash residue (aNDFom, ADFom and ADL, respectively). The total condensed tannins (TCT) content was determined by the butanol-HCl method according to Makkar et al. (1995) using a spectrophotometer (UviLine 8100, SI Analytics - Xylem Analytics Germany Sales GmbH \& Co. KG, Mainz, Germany). Non-fibrous carbohydrate (NFC) levels were calculated using the following formula (NRC, 2001):

$\operatorname{NFC}\left(\mathrm{g} \cdot \mathrm{kg}^{-1}\right)=100-($ aNDFom $+\mathrm{CP}+\mathrm{EE}+\mathrm{ash})$

Analyses were carried out in duplicate for 6 samples of each maturity stage.

The carotenoids ( $\alpha$-carotene, $\beta$-carotene, $\gamma$-carotene, lutein, lycopene and zeaxanthin) were extracted from herbage samples and determined according to the method of Kara and Baytok (2017) in cool and sunlight free laboratory conditions. About $2.0 \mathrm{~g}$ of dried plant sample was weighed into a $15-\mathrm{ml}$ conic centrifuge tube (Isolab, Wertheim, Germany). The methanol $(5 \mathrm{ml})$ and $30 \%$ of methanolic potassium hydroxide $(1 \mathrm{ml})$ were added into tube and mixed using a vortex at $2000 \mathrm{rpm}$ for $30 \mathrm{~min}$ (Velp Vortex ZXClassic, Velp Scientifica, Usmate, Italy), and then incubated in thermostatically controlled cabinet at $4{ }^{\circ} \mathrm{C}$ (Lovibond, Dortmund, Germany). After incubation, tubes were centrifuged in a cooling centrifuge (Nüve NF800R, Nüve, Ankara, Turkey) at $4000 \mathrm{rpm}$ and at $4{ }^{\circ} \mathrm{C}$ for $5 \mathrm{~min}$. Supernatant was decanted into a 50-ml conic centrifuge tube (LP Italiana SPA, Milano, Italy). Extraction procedure was repeated twice with $8 \mathrm{ml}$ of a solvent (hexane, ethanol or petroleum ether), and extracts were pooled. On top of pure and separate extracts, $25 \mathrm{ml}$ of saturated aqueous sodium chloride was added and the mixture shaken. Pooled extracts were read exactly for volume determination. The absorbance values of extracts were measured using a UviLine 9100 spectrophotometer (SI Analytics - Xylem Analytics Germany Sales GmbH \& Co. KG, Mainz, Germany). The $\alpha$-carotene content was determined at $445 \mathrm{~nm}$ and $2710 \mathrm{~A}^{1 \%}{ }_{1 \mathrm{~cm}}$ using hexane as solvent. The $\beta$-carotene content was estimated at $450 \mathrm{~nm}$ and $2620 \mathrm{~A}^{1 \%}$ lcm using ethanol as solvent. The $\gamma$-carotene content was determined at $462 \mathrm{~nm}$ and $2760 \mathrm{~A}^{1 \%}{ }_{1 \mathrm{~cm}}$ using hexane as solvent. The lycopene content was determined at $470 \mathrm{~nm}$ and $3450 \mathrm{~A}^{1 \%}{ }_{1 \mathrm{~cm}}$ using petroleum ether as solvent. The lutein content was estimated at $445 \mathrm{~nm}$ and $2550 \mathrm{~A}^{1 \%}{ }_{1 \mathrm{~cm}}$ using ethanol as solvent. The zeaxanthin content was determined at $449 \mathrm{~nm}$ and $2348 \mathrm{~A}^{1 \%}{ }_{1 \mathrm{~cm}}$ using petroleum ether as solvent (Rodriguez-Amaya, 1999).

Carotenoid concentration were estimated by the following formula:

carotenoid concentration $\left(\mathrm{mg} \cdot \mathrm{kg}^{-1}\right)=(\mathrm{A} \times \mathrm{V} \times$ $\left.\times 10^{4}\right) /\left(\mathrm{A}^{1 \%}{ }_{1 \mathrm{~cm}} \times \mathrm{W}\right)$

where: A - absorbance, $\mathrm{V}$ - volume of extracts $(\mathrm{ml})$, $\mathrm{A}^{1 \%}{ }_{1 \mathrm{~cm}}$ - absorption coefficient, $\mathrm{W}$ - sample weight.

Total saponin (TSP) content of herbage samples was determined according to the modified technique of Vador et al. (2012). The approximately $50 \mathrm{mg}$ of milled herbage samples were extracted using a $5 \mathrm{ml}$ of $99.9 \%$ methanol. The TSP content determination was carried out using $p$-anisaldehyde reagent. The $p$-anisaldehyde reagent was prepared in 1:1 of distilled water:absolute methanol. The $2 \mathrm{ml}$ of sample extract was mixed with $500 \mu \mathrm{l}$ of $0.5 \% p$-anisealdehyde reagent at $2000 \mathrm{rpm}$ for $2 \mathrm{~min}$ using a vortex (Velp Mixer Classic, Velp Scientifica, Usmate, Italy), and kept aside for 10 min at room conditions. The $2 \mathrm{ml}$ of $50 \%$ sulphuric acid reagent was added 
into tubes, and mixture was mixed. The tubes were incubated at $60{ }^{\circ} \mathrm{C}$ for $60 \mathrm{~min}$ (Binder Model FD 23, Binder $\mathrm{GmbH}$, Baddeckenstedt, Germany) and then tubes were cooled, and absorbance of supernatants was read at $430 \mathrm{~nm}$ using a spectrophotometer (UviLine 9100, SI Analytics - Xylem Analytics Germany Sales GmbH \& Co. KG, Mainz, Germany). The amount of TSP was calculated as saponin equivalent from the calibration curve of standard saponin $\left(2-200 \mu \mathrm{g} \cdot \mathrm{ml}^{-1}\right)$.

\section{In vitro digestion technique for ruminants}

Fresh rumen fluid was used as inoculum. Rumen fluid was obtained from two beef cattle (Simmental 16 months of age and about $600 \mathrm{~kg}$ body weight) fed diet containing $80 \%$ concentrated mixture feed and $20 \%$ forage in dry matter (DM) basis $(3.78 \mathrm{~kg}$ flaked maize grain, $3.60 \mathrm{~kg}$ barley grain, $1.30 \mathrm{~kg}$ maize silage, $0.63 \mathrm{~kg}$ wheat straw, $30 \mathrm{~g}$ salt and $20 \mathrm{~g}$ vitaminmineral premix as DM for a day; in total $9.36 \mathrm{~kg} \mathrm{DM} /$ cattle/day) applied an intensive fattening. An approximately 11 of rumen fluid was received using a stomach tube after the morning feeding. It was collected into a thermos under $\mathrm{CO}_{2}$ gas, and filtered with four layers of cheesecloth in the laboratory. The technique was carried out according to the procedures of Menke and Steingass (1988). One litre of buffer mixture included $474 \mathrm{ml}$ of bi-distilled water, $237.33 \mathrm{ml}$ of macro-mineral solution $\left(5.7 \mathrm{~g} \mathrm{Na}_{2} \mathrm{HPO}_{4}, 6.2 \mathrm{~g} \mathrm{KH}_{2} \mathrm{PO}_{4}\right.$ and $0.6 \mathrm{~g}$ $\mathrm{MgSO}_{4}$ in 11 bi-distilled water), $237.33 \mathrm{ml}$ buffer solution $\left(35 \mathrm{~g} \mathrm{NaHCO}_{3}\right.$ and $4 \mathrm{~g} \mathrm{NH}_{4} \mathrm{HCO}_{3}$ in 11 bidistilled water), $0.12 \mathrm{ml}$ trace mineral solution $(13.2 \mathrm{~g}$ $\mathrm{CaCl}_{2} * 2 \mathrm{H}_{2} \mathrm{O}, 10 \mathrm{~g} \mathrm{MnCI}_{2} * 4 \mathrm{H}_{2} \mathrm{O}, 1 \mathrm{~g} \mathrm{CoCl}_{2} * 6 \mathrm{H}_{2} \mathrm{O}$ and $0.8 \mathrm{~g} \mathrm{FeCl}_{3}-* 6 \mathrm{H}_{2} \mathrm{O}$ in $100 \mathrm{ml}$ bi-distilled water), $1.22 \mathrm{ml}$ resazurin solution $(0.1 \mathrm{~g}$ resazurin in $100 \mathrm{ml}$ bi-distilled water) and $50 \mathrm{ml}$ reducing solution (285 mg Na $2 \mathrm{~S}^{*} 7 \mathrm{H}_{2} \mathrm{O}$ and $4 \mathrm{ml} 1 \mathrm{~N} \mathrm{NaOH}$ in $96 \mathrm{ml}$ bi-distilled water). Dried plant samples $(200 \pm 10 \mathrm{mg})$ milled through a $1 \mathrm{~mm}$ sieve were incubated in rumen fluid and buffer mixture in $100 \mathrm{ml}$ glass syringes (Fortuna ${ }^{\circledR}$, Poulten \& Graf Ltd., Wertheim, Germany) $(\mathrm{n}=6$; three syringes for cumulative gas production and three syringes for dry matter-organic matter loss). Thirty millilitres of the rumen fluid plus buffer mixture at a 1:2(v/v) ratio was added into each syringe. In addition, three blank syringes (no template; rumen fluid plus buffer mixture) were incubated to calculate the total gas production. After closing the clips on the inlet silicon tube of the syringe, the syringes were manually shaken and the clips were opened to remove gas by pushing the piston upwards to achieve complete gas removal. The clips were closed, the initial volume recorded and the syringes were incubated in a water bath at $39^{\circ} \mathrm{C}$ for up to $96 \mathrm{~h}$.

\section{In vitro digestion technique for horses}

Fresh faeces samples were used as inoculum and were obtained from two thoroughbred horses (6-7 years of age, $480-500 \mathrm{~kg}$ body weight) fed diet containing $96 \%$ forage and $4 \%$ concentrate, as DM basis $(5.4 \mathrm{~kg}$ meadow hay, $2.25 \mathrm{~kg}$ wheat straw, $0.9 \mathrm{~kg}$ lucerne herbage, $0.36 \mathrm{~kg}$ crushed oat grain, $20 \mathrm{~g}$ salt and $10 \mathrm{~g}$ vitamin-mineral premix; totally $8.94 \mathrm{~kg} \mathrm{DM} /$ horse/day). Faeces samples were collected immediately after defecation and transferred into a thermos containing water at $39{ }^{\circ} \mathrm{C}$ under $\mathrm{CO}_{2}$ gas and transferred to the laboratory within $1 \mathrm{~h}$. Faeces samples were diluted at a $1: 10$ ratio with $0.9 \%$ sterile serum physiologic solution (Polifleks, Polifarma, İstanbul, Turkey) using a laboratory type blender (Waring Products Division, Torrington, CT, USA). Diluted faeces inoculum was filtered through four layers of cheesecloth under constant $\mathrm{CO}_{2}$ gas (anaerobically) and used in the in vitro digestion technique.

The in vitro digestion technique was carried out in glass syringes with $100 \mathrm{ml}$ volume (Fortuna ${ }^{\circledR}$, Poulten \& Graf Ltd., Wertheim, Germany) using the medium mixture (Table 2) prepared according to Sunvold et al. (1995) and Sweeney (2012). The samples $(500 \pm 10 \mathrm{mg}$ as DM) were incubated with medium mixture $(30 \mathrm{ml})$ and faeces inoculum $(5 \mathrm{ml})$ in glass

Table 2. Composition of in vitro fermentation medium

\begin{tabular}{|c|c|}
\hline Component & Amount \\
\hline \multicolumn{2}{|l|}{$\mathrm{ml} \cdot \mathrm{l}^{-1}$} \\
\hline solution $A^{a}$ & 330.0 \\
\hline solution $\mathrm{B}^{\mathrm{b}}$ & 330.0 \\
\hline trace mineral solution ${ }^{c}$ & 10.0 \\
\hline water-soluble vitamins ${ }^{d}$ & 20.0 \\
\hline folate:biotin solution & 5.0 \\
\hline riboflavin solution ${ }^{f}$ & 5.0 \\
\hline hemin solution ${ }^{g}$ & 2.5 \\
\hline short chain fatty acids ${ }^{h}$ & 0.4 \\
\hline resazurine ${ }^{i}$ & 1.0 \\
\hline distilled water & 296.0 \\
\hline \multicolumn{2}{|l|}{$g \cdot l^{-1}$} \\
\hline yeast extract & 0.5 \\
\hline trypticase & 0.5 \\
\hline $\mathrm{Na}_{2} \mathrm{CO}_{3}$ & 4.0 \\
\hline cysteine $\mathrm{HCl}^{*} \mathrm{H}_{2} \mathrm{O}$ & 0.5 \\
\hline
\end{tabular}

a composition, g $\cdot \mathrm{I}^{-1}: \mathrm{NaCl} 5.4, \mathrm{KH}_{2} \mathrm{PO}_{4}$ 2.7, $\mathrm{CaCl}_{2}{ }^{*} \mathrm{H}_{2} \mathrm{O}$ 0.16, $\left.\mathrm{MgCl}_{2}{ }^{*} 6 \mathrm{H}_{2} \mathrm{O} 0.12, \mathrm{MnCl}_{2}{ }^{*} 4 \mathrm{H}_{2} \mathrm{O} 0.06, \mathrm{CoCl}_{2}{ }^{*} 6 \mathrm{H}_{2} \mathrm{O} 0.06,\left(\mathrm{NH}_{4}\right)_{2}\right)_{2} \mathrm{SO}_{4} 5.4$; ${ }^{\mathrm{b}}$ composition, $\mathrm{g} \cdot \mathrm{I}^{-1}: \mathrm{K}_{2} \mathrm{HPO}_{4} 2.7$; ${ }^{\mathrm{C}}$ composition, $\mathrm{mg} \cdot \mathrm{I}^{-1}:$ ethylene diamine tetraacetic acid (disodium salt) $500, \mathrm{FeSO}_{4}{ }^{*} 7 \mathrm{H}_{2} \mathrm{O} 200$, $\mathrm{ZnSO}_{4}{ }^{*} 7 \mathrm{H}_{2} \mathrm{O} \quad 10, \quad \mathrm{MnCl}_{2}{ }^{*} 4 \mathrm{H}_{2} \mathrm{O} \quad 3, \mathrm{H}_{3} \mathrm{PO}_{4} \quad 30, \mathrm{CoCl}_{2}{ }^{*} 6 \mathrm{H}_{2} \mathrm{O} \quad 20$, $\mathrm{CuCl}_{2}{ }^{4} 2 \mathrm{H}_{2} \mathrm{O} 1, \mathrm{NiCl}_{2}{ }^{*} 6 \mathrm{H}_{2} \mathrm{O} 2, \mathrm{Na}_{2} \mathrm{MoO}_{4}{ }^{*} 2 \mathrm{H}_{2} \mathrm{O} 3$; ${ }^{\mathrm{d}}$ composition, $\mathrm{mg} \cdot \mathrm{I}^{-1}$ : thiamin-HCl 100, d-pantothenic acid 100, niacin 100, pyridoxine 100 ,

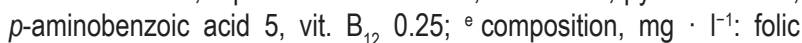
acid 10, d-biotin 2, $\mathrm{NH}_{4} \mathrm{HCO}_{3} 100$; ${ }^{\mathrm{f}}$ composition: riboflavin $10 \mathrm{mg} \cdot \mathrm{l}^{-1}$ in $5 \mathrm{mmol} \cdot \mathrm{I}^{-1}$ of HEPES; ${ }^{9} \mathrm{Hemin}$ : Hemin $500 \mathrm{mg} \cdot \mathrm{I}^{-1}$ of $10 \mathrm{mmol} \cdot \mathrm{l}^{-1}$ $\mathrm{NaOH} ;{ }^{\text {h }}$ composition: $n$-valerate, isovalerate, isobutyrate and DL-alphamethylbutyrate, $\left.250 \mathrm{ml} \cdot\right|^{-1} ;$ icomposition: 1 g resazurine $\cdot l^{-1}$ distilled water 
syringes $(n=6)$. The syringes were closed using clips and then the initial volume recorded and incubated in a water bath with thermostat (Special Waterbath, Yapar Stainless Steel Ltd., Kahramanmaras, Turkey) at $39.0 \pm 0.2{ }^{\circ} \mathrm{C}$ up to $48 \mathrm{~h}$. In addition, six blank syringes (no template; medium mixture plus faeces inoculum) were used to calculate the total gas production.

\section{Determination of cumulative gas production}

In incubations, the total gas volume was recorded from the calibrated scale on the syringe at 3,6 , $12,18,24,36,48,72$ and $96 \mathrm{~h}$ for ruminants, and at $3,6,12,18,24,36$ and $48 \mathrm{~h}$ for horses.

\section{Determination of total gas and methane production}

After measuring the total gas volume at $24 \mathrm{~h}$, the tubing of the plastic syringe outlet was inserted into the inlet of the methane analyser (Sensor Europe $\mathrm{GmbH}$, Erkrath, Germany) and the piston was pushed to insert the accumulated gas into the analyser (Kara et al., 2015).

\section{Determination of volatile fatty acids (VFAs), in vitro true dry matter disappearance and in vitro true organic matter disappearance}

Three of the fermentation syringes for both ruminants and horses were stopped after $24 \mathrm{~h}$, and then the VFAs concentrations in fermentation fluids and in vitro true dry matter disappearance (T-DMd) and the in vitro true organic matter disappearance (T-OMd) were analysed.

The in vitro dry matter and organic matter disappearance was determined by filtering the fermentation residues using a vacuum unit (Velp Dietary Fibre Analyzer, Velp Scientifica, Usmate, Italy) on pre-weighed glass crucibles (porosity \#2, Velp Scientifica, Usmate, Italy) dried at $105^{\circ} \mathrm{C}$ and burning the residual at $550{ }^{\circ} \mathrm{C}$.

In vitro $\mathrm{T}-\mathrm{DMd}$ was calculated as:

$\mathrm{T}-\mathrm{DMd}=1-[(\mathrm{DM}$ residue $-\mathrm{DM}$ blank $) /$ initial $\mathrm{DM})] \times 100$.

In vitro $\mathrm{T}-\mathrm{OMd}$ was calculated as: $\mathrm{T}-\mathrm{OMd}=1-[(\mathrm{OM}$ residue - OM blank $) /$ initial $\mathrm{OM})] \times 100$.

After measuring the total gas volume at $24 \mathrm{~h}$ of in vitro incubation, approximately $10 \mathrm{ml}$ digestion fluid in each syringe was collected in Falcon tubes. The digestion fluid was filtered through four layers of cheesecloth, and $2 \mathrm{ml}$ digestion fluid was

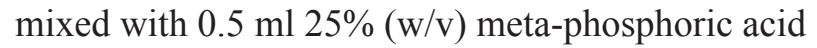
and kept frozen $\left(-20{ }^{\circ} \mathrm{C}\right)$ for the analysis of VFAs in microcentrifuge tubes. The frozen samples were thawed at $4{ }^{\circ} \mathrm{C}$ and centrifuged at $15000 \mathrm{~g}$ for $15 \mathrm{~min}$ using a microcentrifuge (Gyrozen 1524, Daejeon, South Korea). After, the supernatants were filtered using a syringe-driven filter unit with a $0.22 \mathrm{~mm}$ pore diameter (Millex Filter Unit, Merck Millipore Ltd., Tullagreen, Ireland), the filtrates were transferred into the vials (Chromacol, Thermo Fisher Scientific, Orlando, FL, USA). Analysis of the VFAs was carried out using a gas chromatograph (TRACE ${ }^{\mathrm{TM}}$ 1300, Thermo Fisher Scientific, Orlando, FL, USA) equipped with an auto sampler (AI 1310, Thermo Scientific, Orlando, FL, USA), a polyethylene glycol column (length: $60 \mathrm{~m}$, i.d: $0.25 \mathrm{~mm}$, film thickness: $0.25 \mu \mathrm{m})$ (TG-WAXMS, Thermo Scientific, Orlando, FL, USA) and a flame ionization detector (FID). The carrier gas was helium at a constant flow rate of $1.5 \mathrm{ml} \cdot \mathrm{min}^{-1}$. The injection volume was $0.5 \mu 1$. The samples were injected with split mode. The injection port temperature was $280{ }^{\circ} \mathrm{C}$. Oven temperature was programmed to increase from $160{ }^{\circ} \mathrm{C}$ to $180{ }^{\circ} \mathrm{C}$ at a rate $20^{\circ} \mathrm{C} \cdot \mathrm{min}^{-1}$. Air flow was $350 \mathrm{ml} \cdot \mathrm{min}^{-1}$, and hydrogen flow was $35 \mathrm{ml} \cdot \mathrm{min}^{-1}$. The temperature of FID detector was $300^{\circ} \mathrm{C}$. Oven run time was $10 \mathrm{~min}$. The concentrations of VFAs expressed as $\mathrm{mmol} \cdot 1^{-1}$ were identified using a Xcalibur software programme (Thermo Scientific, Orlando, FL, USA). The percentage of VFA [acetic (A), butyric (B) and propionic (P) acids], and $\mathrm{A} / \mathrm{P}$ and $(\mathrm{A}+\mathrm{B}) / \mathrm{P}$ ratios were calculated.

\section{Estimation of metabolizable energy, gas yield, partial factor and microbial crude protein production levels}

The metabolizable energy (ME) contents of the samples were calculated using the equations of Menke and Steingass (1988) as follows:

$$
\begin{gathered}
\mathrm{ME}\left(\mathrm{MJ} \cdot \mathrm{kg}^{-1} \mathrm{DM}\right)=2.20+0.136 \times \mathrm{GP}+ \\
\quad+0.0057 \times \times \mathrm{CP}+0.00029 \times \mathrm{EE}^{2}
\end{gathered}
$$

where: GP $-24 \mathrm{~h}$ net gas production $\left(\mathrm{ml} \cdot 0.2 \mathrm{~g}^{-1}\right.$ $\mathrm{DM}), \mathrm{CP}$ - crude protein $\left(\mathrm{g} \cdot \mathrm{kg}^{-1} \mathrm{DM}\right), \mathrm{EE}$ - ether extract $\left(\mathrm{g} \cdot \mathrm{kg}^{-1} \mathrm{DM}\right)$.

The gas yields $\left(\mathrm{GY}_{24}\right)$, partial factor $\left(\mathrm{PF}_{24}\right)$ and microbial crude protein production levels (MCP) of the samples at $24 \mathrm{~h}$ were calculated using the equations of Elghandour et al. (2015):

$$
\begin{gathered}
\mathrm{GY}_{24}\left(\mathrm{ml} \cdot \mathrm{g}^{-1} \mathrm{DM}\right)=\left(\mathrm{GP}_{24} \times 10^{3}\right) / \mathrm{T}-\mathrm{DMd} \\
\mathrm{PF}_{24}\left(\mathrm{mg} \cdot \mathrm{ml}^{-1} \mathrm{GP}_{24}\right)=\mathrm{T}-\mathrm{DMd} / \mathrm{GP}_{24} \\
\mathrm{MCP}\left(\mathrm{mg} \cdot \mathrm{g}^{-1} \mathrm{DM}\right)=\mathrm{mg} \mathrm{T}-\mathrm{DMd}-\left(\mathrm{ml} \mathrm{GP}_{24} \times\right. \\
\left.\times 2.2 \mathrm{mg} \cdot \mathrm{ml}^{-1}\right)
\end{gathered}
$$

where: $\mathrm{GP}_{24}$ - volume $(\mathrm{ml})$ of total gas produced by $\mathrm{g} \mathrm{DM}$ at $24 \mathrm{~h}\left(\mathrm{ml} \cdot \mathrm{g}^{-1} \mathrm{DM}\right), \mathrm{T}-\mathrm{DMd}$ - in vitro dry matter disappearance $(\mathrm{mg})$ for $\mathrm{g}$ DM at $24 \mathrm{~h}\left(\mathrm{mg} \cdot \mathrm{g}^{-1} \mathrm{DM}\right)$. 


\section{Statistical analysis}

Firstly, the data were subjected to Levene's test to detect the variance homogeneity. One-way variance analyses (ANOVA) were implemented for homogeneous variances by General Linear Model procedures to test treatment differences. Data was analysed based on the statistical model:

$$
\mathrm{Y} i j=\mu i j+\mathrm{S} i+\mathrm{e} i
$$

where: $Y i j-$ general mean common for each parameter under investigation, $\mathrm{S} i-i^{\text {th }}$ effect of maturity stages of Jerusalem artichoke herbage on the observed parameters, e $i-$ standard error term. The means were separated by Tukey's multiple range test at $P<0.05$.

Linear relations among the maturity stage and chemical composition with gas production values and some estimated parameters were determined using Pearson's correlation coefficients $(r)$.

Analyses were performed using a SPSS 17.0 software (IBM Corp., Armonk, NY, USA).

\section{Results}

\section{Nutrient composition of Jerusalem artichoke herbage harvested at different maturity stages}

The CP content of Jerusalem artichoke herbage was $16.36 \%$ at the vegetative stage; otherwise this value decreased to $6.59 \%$ with plant maturation
$(P<0.001)$. The ash content was different according to maturity stages: $13.64 \%$ at the vegetative, $11.73 \%$ at the early flowering, $11.16 \%$ at full flowering and $8.9 \%$ at early seeding $(P=0.007)$. The EE content of Jerusalem artichoke herbage ranged from $0.94 \%$ to $2.19 \%(P<0.001)$. The aNDFom $(P=0.019)$, ADFom $(P=0.005)$ and ADL $(P=0.024)$ increased with plant maturation and NFC content decreased $(P=0.027)$. The TCT content $(0.47 \%)$ at the early seeding stage was higher than $(0.35 \%)$ at the vegetative stage. The TSP content ranged from 1.66 to $0.43 \mathrm{mg} \cdot \mathrm{g}^{-1} \mathrm{DM}$, and decreased with plant maturation $(P<0.001)$.

The individual carotenoids composition of herbage was the highest in the full flowering stage $(P<0.001)$. The $\beta$-carotene, $\alpha$-carotene, $\gamma$-carotene, lycopene, zeaxanthin and total carotenoid content in the examined herbage increased from the vegetative stage up to the full flowering stage, and then decreased at the early seeding stage $(P<0.001)$. The lutein content was higher than the other carotenoids except early flowering maturity stage. In addition, the lowest concentration of carotenoids was determined for $\beta$-carotene at the early seeding stage (Table 3 ).

\section{In vitro digestion parameters of Jerusalem artichoke herbage in horses}

In horses the in vitro cumulative gas production of Jerusalem artichoke herbage at vegetative stage

Table 3. Nutrient composition of Jerusalem artichoke herbage harvested at different maturity stages

\begin{tabular}{|c|c|c|c|c|c|c|c|}
\hline \multirow[b]{2}{*}{ Indices } & \multicolumn{4}{|c|}{ Maturity stages } & \multirow[b]{2}{*}{ SD } & \multirow[b]{2}{*}{ SEM } & \multirow[b]{2}{*}{$P$-value } \\
\hline & vegetative & $\begin{array}{l}\text { early } \\
\text { flowering }\end{array}$ & $\begin{array}{l}\text { full } \\
\text { flowering }\end{array}$ & $\begin{array}{l}\text { early } \\
\text { seeding }\end{array}$ & & & \\
\hline \multicolumn{8}{|l|}{$\% \mathrm{DM}$} \\
\hline $\mathrm{CP}$ & $16.36^{a}$ & $7.37^{b}$ & $7.14^{\mathrm{b}}$ & $6.59^{b}$ & 4.33 & 1.53 & $<0.001$ \\
\hline aNDFom & $28.79^{b}$ & $39.03^{\mathrm{ab}}$ & $40.63^{a}$ & $44.74^{\mathrm{a}}$ & 6.62 & 2.34 & 0.019 \\
\hline ADFom & $27.37^{c}$ & $31.70^{\text {bc }}$ & $33.36^{a b}$ & $36.69^{a}$ & 3.67 & 1.30 & 0.005 \\
\hline$A D L$ & $5.65^{b}$ & $6.78^{a b}$ & $7.39^{a}$ & $8.82^{\mathrm{a}}$ & 1.03 & 0.31 & 0.024 \\
\hline EE & $0.94^{b}$ & $1.70^{\mathrm{a}}$ & $1.77^{\mathrm{a}}$ & $2.19^{a}$ & 0.49 & 0.17 & $<0.001$ \\
\hline ash & $13.64^{a}$ & $11.73^{b}$ & $11.16^{b}$ & $8.90^{c}$ & 2.19 & 0.77 & 0.007 \\
\hline NFC & $40.25^{a}$ & $40.15^{\mathrm{a}}$ & $39.28^{a b}$ & $37.56^{\mathrm{b}}$ & 1.35 & 0.83 & 0.027 \\
\hline TCT & $0.35^{b}$ & $0.37^{\mathrm{ab}}$ & $0.42^{\mathrm{ab}}$ & $0.47^{a}$ & 0.06 & 0.01 & 0.037 \\
\hline $\begin{array}{l}\text { TSP, } \mathrm{mg} \cdot \mathrm{g}^{-1} \mathrm{DM} \\
\mathrm{mg} \cdot \mathrm{kg}^{-1} \mathrm{DM}\end{array}$ & $1.66^{\mathrm{a}}$ & $1.14^{b}$ & $0.80^{c}$ & $0.43^{d}$ & 0.47 & 0.13 & $<0.001$ \\
\hline a-carotene & $21.62^{c}$ & $15.22^{\mathrm{d}}$ & $43.36^{a}$ & $26.01^{\mathrm{b}}$ & 11.15 & 3.94 & $<0.001$ \\
\hline$\beta$-carotene & $77.60^{b}$ & $71.96^{b}$ & $104.74^{a}$ & $7.00^{\circ}$ & 34.78 & 11.00 & $<0.001$ \\
\hline Y-carotene & $17.00^{c}$ & $11.63^{d}$ & $33.46^{a}$ & $19.58^{b}$ & 8.61 & 3.04 & $<0.001$ \\
\hline lutein & $80.50^{c}$ & $50.74^{d}$ & $120.14^{a}$ & $83.11^{\mathrm{b}}$ & 26.32 & 9.30 & $<0.001$ \\
\hline lycopene & $17.48^{c}$ & $18.08^{b}$ & $41.12^{\mathrm{a}}$ & $12.06^{\mathrm{d}}$ & 11.95 & 4.22 & $<0.001$ \\
\hline zeaxanthin & $30.43^{b}$ & $30.56^{b}$ & $72.38^{a}$ & $20.02^{c}$ & 21.50 & 7.60 & $<0.001$ \\
\hline TCar & $244.64^{b}$ & $198.96^{b}$ & $415.22^{\mathrm{a}}$ & $167.80^{c}$ & 103.40 & 32.69 & $<0.001$ \\
\hline
\end{tabular}

SD - standard deviation; SEM - standard error of the means; CP - crude protein; aNDFom - neutral detergent fibre assayed with a heat stable amylase and expressed exclusive of residual ash; ADFom - acid detergent fibre expressed exclusive of residual ash; ADL - acid detergent lignin; $\mathrm{EE}$ - diethyl ether extract; NFC - non-fibrous carbohydrate; TCT - total condensed tannin; TSP - total saponin; TCar - total carotenoid = a-carotene + $\beta$-carotene $+y$-carotene + lutein + lycopene + zeaxanthin; ${ }^{a-d}$ - means with different superscripts within the same row are significantly different at $P<0.05$ (Tukey's test) 
was higher than those of other maturity stages (especially at $24 \mathrm{~h}$ ). Generally, cumulative gas production of the early flowering stage was similar to that of the full flowering stage. The in vitro cumulative gas production at the early seeding stage was lower than those of other stages up to $24 \mathrm{~h}$ of incubation $(P<0.001)$ (Table 4).

The in vitro methane production of Jerusalem artichoke herbage was found in a wide range
$0.22-0.33 \mathrm{ml} \cdot \mathrm{g}^{-1} \mathrm{DM}$ at $24 \mathrm{~h}$ for different maturity stages $(P=0.001)$. The in vitro T-DMd, T-OMd and ME values of Jerusalem artichoke herbage for horses were the highest at the vegetative stage and decreased with plant maturation $(P<0.001)$. In addition, the in vitro $\mathrm{GY}_{24}(P=0.116)$, and $\mathrm{PF}_{24}(P=0.090)$ values did not differ between maturity stages. The in vitro $\mathrm{MCP}$ value in vegetative stage was higher than those of other stages $(P=0.001$; Table 5$)$.

Table 4. In vitro cumulative total gas production (GP) of Jerusalem artichoke herbage at different maturity stages in horses and ruminants

\begin{tabular}{|c|c|c|c|c|c|c|c|c|c|}
\hline \multirow{2}{*}{ Maturity stages } & \multicolumn{9}{|c|}{ In vitro cumulative total gas production, hours } \\
\hline & $\mathrm{GP}_{3}$ & $\mathrm{GP}_{6}$ & $\mathrm{GP}_{12}$ & $\mathrm{GP}_{18}$ & $\mathrm{GP}_{24}$ & $\mathrm{GP}_{36}$ & $\mathrm{GP}_{48}$ & $\mathrm{GP}_{72}$ & $\mathrm{GP}_{96}$ \\
\hline \multicolumn{10}{|c|}{ In horses, $\mathrm{ml} \cdot \mathrm{g}^{-1} \mathrm{DM}$} \\
\hline vegetative & 2.14 & $33.8^{\mathrm{a}}$ & $117^{\mathrm{a}}$ & $136^{a}$ & $173^{a}$ & $211^{a}$ & $230^{\mathrm{a}}$ & & \\
\hline early flowering & 4.30 & $21.6^{b}$ & $110^{\mathrm{a}}$ & $126^{\mathrm{ab}}$ & $145^{b}$ & $202^{\mathrm{ab}}$ & $204^{\mathrm{ab}}$ & & \\
\hline full flowering & 5.00 & $18.6^{\mathrm{bc}}$ & $104^{a}$ & $117^{\mathrm{b}}$ & $139^{b}$ & $195^{b}$ & $201^{b}$ & & \\
\hline early seeding & 2.87 & $16.4^{c}$ & $82^{b}$ & $94^{c}$ & $110^{c}$ & $195^{b}$ & $200^{b}$ & & \\
\hline SEM & 0.36 & 1.30 & 4.05 & 4.80 & 6.30 & 2.60 & 4.41 & & \\
\hline SD & 1.77 & 6.42 & 19.86 & 23.51 & 30.85 & 9.01 & 15.30 & & \\
\hline$P$-value & 0.122 & $<0.001$ & $<0.001$ & $<0.001$ & $<0.001$ & 0.041 & 0.016 & & \\
\hline \multicolumn{10}{|c|}{ In ruminants, $\mathrm{ml} \cdot \mathrm{g}^{-1} \mathrm{DM}$} \\
\hline vegetative & $32.2^{\mathrm{a}}$ & $139^{a}$ & $168^{a}$ & $185^{\mathrm{a}}$ & $220^{a}$ & $219^{a}$ & $227^{a}$ & $232^{\mathrm{a}}$ & $239^{a}$ \\
\hline early flowering & $30.5^{\mathrm{a}}$ & $137^{a}$ & $143^{\mathrm{ab}}$ & $173^{\mathrm{ab}}$ & $192^{\mathrm{ab}}$ & $204^{\mathrm{ab}}$ & $202^{\mathrm{ab}}$ & $208^{a b}$ & $211^{a b}$ \\
\hline full flowering & $30.0^{\mathrm{ab}}$ & $120^{a b}$ & $129^{b}$ & $154^{b}$ & $171^{\mathrm{ab}}$ & $174^{\mathrm{ab}}$ & $180^{a b}$ & $187^{\mathrm{ab}}$ & $185^{b}$ \\
\hline early seeding & $17.9^{b}$ & $104^{b}$ & $123^{b}$ & $146^{b}$ & $155^{b}$ & $168^{b}$ & $175^{b}$ & $181^{b}$ & $186^{b}$ \\
\hline SEM & 2.52 & 4.28 & 4.37 & 5.66 & 7.23 & 6.18 & 5.80 & 5.66 & 5.93 \\
\hline SD & 8.74 & 14.83 & 5.14 & 19.62 & 25.05 & 21.42 & 20.10 & 19.62 & 20.56 \\
\hline$P$-value & 0.014 & 0.003 & 0.027 & 0.022 & 0.039 & 0.032 & 0.049 & 0.027 & 0.015 \\
\hline
\end{tabular}

DM - dry matter; SEM - standard error of the means; SD - standard deviation; ab - means with different superscripts within the same column for ruminants and horses separately are different at $P<0.05$ (Tukey's test)

Table 5. In vitro digestion values of Jerusalem artichoke herbage at different maturity stages in horses and ruminants

\begin{tabular}{|c|c|c|c|c|c|c|c|}
\hline Maturity stages & Methane & T-DMd & T-OMd & $\mathrm{GY}_{24}$ & $\mathrm{PF}_{24}$ & $\mathrm{ME}$ & MCP \\
\hline \multicolumn{8}{|l|}{ In horses } \\
\hline vegetative & $0.28^{\mathrm{ab}}$ & $578^{a}$ & $650^{\mathrm{a}}$ & 299 & 3.34 & $7.86^{\mathrm{a}}$ & $323^{a}$ \\
\hline early flowering & $0.30^{\mathrm{a}}$ & $488^{b}$ & $553^{b}$ & 297 & 3.37 & $6.62^{\mathrm{b}}$ & $169^{b}$ \\
\hline full flowering & $0.32^{\mathrm{a}}$ & $462^{b}$ & $526^{b}$ & 301 & 3.32 & $6.50^{\mathrm{b}}$ & $156^{b}$ \\
\hline early seeding & $0.22^{b}$ & $434^{b}$ & $480^{\circ}$ & 253 & 3.94 & $5.70^{c}$ & $192^{b}$ \\
\hline SEM & 0.02 & 16.47 & 20.30 & 7.84 & 0.22 & 0.23 & 12.87 \\
\hline SD & 0.06 & 57.06 & 70.34 & 32.57 & 0.42 & 0.82 & 78.21 \\
\hline$P$-value & 0.001 & $<0.001$ & $<0.001$ & 0.116 & 0.090 & $<0.001$ & 0.001 \\
\hline \multicolumn{8}{|l|}{ In ruminants } \\
\hline vegetative & $39.82^{\mathrm{a}}$ & $556^{\mathrm{a}}$ & $678^{a}$ & 396 & 2.53 & $8.96^{\mathrm{a}}$ & $72^{b}$ \\
\hline early flowering & $38.46^{\mathrm{a}}$ & $544^{a}$ & $580^{b}$ & 353 & 2.83 & $7.96^{\mathrm{ab}}$ & $122^{\mathrm{a}}$ \\
\hline full flowering & $35.79^{a}$ & $492^{\mathrm{ab}}$ & $593^{b}$ & 348 & 2.88 & $7.92^{\mathrm{b}}$ & $116^{a}$ \\
\hline early seeding & $30.31^{b}$ & $438^{b}$ & $574^{b}$ & 356 & 2.81 & $6.93^{c}$ & $95^{b}$ \\
\hline SEM & 1.20 & 9.59 & 8.39 & 10.40 & 0.11 & 0.23 & 6.65 \\
\hline SD & 6.83 & 27.87 & 23.73 & 35.42 & 0.30 & 0.81 & 51.30 \\
\hline$P$-value & 0.003 & 0.014 & 0.015 & 0.671 & 0.690 & 0.001 & 0.004 \\
\hline
\end{tabular}

$\mathrm{DM}$ - dry matter; methane - in vitro methane production as $\mathrm{ml} \cdot \mathrm{g}^{-1} \mathrm{DM}$ at $24 \mathrm{~h}$ (methane production, $\mathrm{ml}=\left(\mathrm{GP}_{24}\right.$, $\mathrm{ml} \times$ methane as percent in $\left.\left.\mathrm{GP}_{24}\right) / 100\right) ; \mathrm{GP}_{24}$ - volume $(\mathrm{ml})$ of total gas produced by $\mathrm{g} \mathrm{DM}$ at $24 \mathrm{~h}\left(\mathrm{ml} \cdot \mathrm{g}^{-1} \mathrm{DM}\right) ; \mathrm{T}$-DMd - in vitro true dry matter disappearance $(\mathrm{mg})$ for $\mathrm{g} \mathrm{DM}$ at $24 \mathrm{~h}\left(\mathrm{mg} \cdot \mathrm{g}^{-1} \mathrm{DM}\right) ; \mathrm{T}-\mathrm{OMd}$ - in vitro true organic matter disappearance $(\mathrm{mg}) ; \mathrm{GY}_{24}$ - gas yield is total gas volume (ml) produced for $\mathrm{g}$ T-DMd at $24 \mathrm{~h}\left(\mathrm{ml} \cdot \mathrm{g}^{-1} \mathrm{DM}\right) ; \mathrm{PF}_{24}$ - partial factor is ratio T-DMd to $\mathrm{GP}_{24}$ at $24 \mathrm{~h}\left(\mathrm{mg} \cdot \mathrm{ml}^{-1} \mathrm{GP}_{24}\right) ; \mathrm{ME}$ - metabolizable energy as $\mathrm{MJ} \cdot \mathrm{kg}^{-1} \mathrm{DM} ; \mathrm{MCP}-$ microbial crude protein produced at $24 \mathrm{~h}\left(\mathrm{mg} \cdot \mathrm{g}^{-1} \mathrm{DM}\right)$; SEM - standard error of the means; SD - standard deviation; abc - means with different superscripts within the same column for ruminants and horses separately are different at $P<0.05$ (Tukey's test) 
Table 6. Effect of Jerusalem artichoke herbage on organic acid composition in digestion fluid in horses and ruminants in vitro

\begin{tabular}{|c|c|c|c|c|c|c|c|c|c|}
\hline \multirow[t]{2}{*}{ Maturity stages } & $\begin{array}{l}\text { Acetic } \\
\text { acid }\end{array}$ & $\begin{array}{l}\text { Propionic } \\
\text { acid }\end{array}$ & $\begin{array}{l}\text { Butyric } \\
\text { acid }\end{array}$ & VFAs & $\begin{array}{l}\text { Acetic } \\
\text { acid }\end{array}$ & $\begin{array}{l}\text { Propionic } \\
\text { acid }\end{array}$ & $\begin{array}{l}\text { Butyric } \\
\text { acid }\end{array}$ & \multirow[t]{2}{*}{$\mathrm{A} / \mathrm{P}$} & \multirow[t]{2}{*}{$(A+B) / P$} \\
\hline & \multicolumn{4}{|c|}{$\mathrm{mmol} \cdot \mathrm{I}^{-1}$} & \multicolumn{3}{|c|}{$\%$} & & \\
\hline \multicolumn{10}{|l|}{ In horses } \\
\hline vegetative & $53.03^{a}$ & $28.20^{a}$ & $9.24^{\mathrm{a}}$ & $90.49^{a}$ & 58.61 & 31.16 & $10.21^{\mathrm{ab}}$ & 1.88 & 2.20 \\
\hline early flowering & $48.83^{\mathrm{ab}}$ & $25.56^{b}$ & $8.61^{\mathrm{ab}}$ & $83.01^{\mathrm{ab}}$ & 58.82 & 30.79 & $10.37^{a}$ & 1.91 & 2.24 \\
\hline full flowering & $48.21^{b}$ & $25.43^{b}$ & $8.21^{b}$ & $81.86^{b}$ & 58.88 & 31.07 & $10.03^{b}$ & 1.89 & 2.21 \\
\hline early seeding & $47.78^{b}$ & $25.32^{b}$ & $8.09^{b}$ & $81.19^{b}$ & 58.84 & 31.18 & $9.96^{b}$ & 1.88 & 2.20 \\
\hline SEM & 0.75 & 0.43 & 0.15 & 1.33 & 0.08 & 0.09 & 0.05 & 0.008 & 0.01 \\
\hline SD & 2.62 & 1.50 & 0.53 & 4.61 & 0.29 & 0.32 & 0.01 & 0.02 & 0.03 \\
\hline$P$-value & 0.019 & 0.019 & 0.007 & 0.015 & 0.737 & 0.471 & 0.014 & 0.653 & 0.467 \\
\hline \multicolumn{10}{|l|}{ In ruminants } \\
\hline vegetative & $53.61^{a}$ & $28.02^{\mathrm{a}}$ & $9.49^{a}$ & $91.13^{\mathrm{a}}$ & 58.83 & $30.75^{b}$ & $10.41^{b}$ & 1.91 & 2.25 \\
\hline early flowering & $52.23^{b}$ & $27.85^{\mathrm{a}}$ & $9.41^{\mathrm{ab}}$ & $89.51^{b}$ & 58.35 & $31.12^{\mathrm{a}}$ & $10.52^{\mathrm{ab}}$ & 1.87 & 2.21 \\
\hline full flowering & $52.50^{b}$ & $27.61^{a b}$ & $9.41^{\mathrm{ab}}$ & $89.52^{b}$ & 58.18 & $30.84^{b}$ & $10.51^{\mathrm{ab}}$ & 1.88 & 2.22 \\
\hline early seeding & $50.85^{c}$ & $27.31^{b}$ & $9.30^{\mathrm{b}}$ & $87.47^{\circ}$ & 58.59 & $31.22^{\mathrm{a}}$ & $10.63^{a}$ & 1.87 & 2.21 \\
\hline SEM & 0.31 & 0.09 & 0.02 & 0.42 & 0.15 & 0.06 & 0.02 & 0.006 & 0.01 \\
\hline SD & 1.08 & 0.32 & 0.08 & 1.45 & 0.53 & 0.21 & 0.10 & 0.02 & 0.02 \\
\hline$P$-value & $<0.001$ & 0.011 & 0.042 & 0.001 & 0.538 & $<0.001$ & 0.041 & 0.076 & 0.057 \\
\hline
\end{tabular}

VFAs - violate fatty acids = acetic acid + propionic acid + butyric acids as $\mathrm{mmol} \cdot \mathrm{I}^{-1}$ in digestion fluid; A/P - acetic acid/propionic acid; $(A+B) / P$ - (acetic acid + butyric acid)/propionic acid; SEM - standard error of the means; SD - standard deviation; abc - means with different superscripts within the same column for ruminants and horses separately are different at $P<0.05$ (Tukey's test)

The molar concentration $\left(\mathrm{mmol} \cdot \mathrm{1}^{-1}\right)$ of acetic acid $(P=0.019)$, propionic acid $(P=0.019)$, butyric acid $(P=0.007)$ and sum of VFAs $(P=0.015)$ in the horse fermentation fluid decreased with plant maturation (Table 6).

\section{In vitro digestion parameters of Jerusalem artichoke herbage in ruminants}

In ruminants, the in vitro cumulative gas production of Jerusalem artichoke herbage decreased with plant maturation up to $96 \mathrm{~h}(P<0.05)$. For cumulative gas production, the difference between the vegetative and the early seed stages was significant $(P<0.05)$.

The in vitro ruminal methane production at $24 \mathrm{~h}$ at the vegetative and early flowering stages was higher than that of other maturity stages $(P=0.003)$. The in vitro T-DMd $(P=0.014)$, T-OMd $(P=0.015)$ and $\operatorname{ME}(P=0.001)$ values decreased with plant maturation but $\mathrm{GY}_{24}(P=0.671)$ and $\mathrm{PF}_{24}(P=0.690)$ did not differ among the maturity stages. The in vitro MCP values in early and full flowering stages were higher than those of vegetative and early seeding stages $(P=0.004)$ (Table 5).

The molar concentration $\left(\mathrm{mmol} \cdot 1^{-1}\right)$ of acetic acid $(P<0.001)$, propionic acid $(P=0.011)$, butyric acid $(P=0.042)$ and total VFA $(P=0.001)$ in the ruminal fermentation fluid of Jerusalem artichoke herbage decreased with plant maturation
(Table 6). However the individual proportions of acetic $(P<0.001)$ and propionic $(P=0.041)$ acids in the digestion fluid increased with plant maturation (Table 6).

\section{Pearson correlation of chemical composition and some in vitro digestion parameters of Jerusalem artichoke herbage in horses}

In horses, maturation of Jerusalem artichoke herbage was negatively correlated with in vitro ME $(r=-0.497), \mathrm{T}-\mathrm{DMd}(r=-0.496), \mathrm{T}-\mathrm{OMd}$ $(r=-0.498), \mathrm{P}(r=-0.606), \mathrm{A}(r=-0.540)$, $(P<0.05)$ and NFC $(r=-0.927)(P<0.01)$; and also positively correlated with aNDFom $(r=0.942)$, ADFom $(r=0.987)$, ADL $(r=0.989)$ and TCT $(r=0.984)(P<0.01$; Table 7).

\section{Pearson correlation of chemical composition and some in vitro digestion parameters of Jerusalem artichoke herbage in ruminants}

Maturation of Jerusalem artichoke herbage was negatively correlated with GP $(r=-0.827)$, $\mathrm{ME}(r=-0.570), \mathrm{T}-\mathrm{DMd}(r=-0.698), \mathrm{T}-\mathrm{OMd}$ $(r=-0.545), \mathrm{B}(r=-0.744), \mathrm{P}(r=-0.848)$, A $(r=-0.864)$ and NFC $(r=-0.927)$; it was also positively correlated with aNDFom $(r=0.942)$, ADFom $(r=0.987)$, ADL $(r=0.989)$ and TCT $(r=0.984)$ for ruminants $(P<0.05)$ (Table 8$)$. 
Table 7. Correlation coefficient (r) relationship of chemical composition and some in vitro digestion parameters of Jerusalem artichoke herbage for horses

\begin{tabular}{|c|c|c|c|c|c|c|c|c|c|c|c|c|}
\hline Indices & $\mathrm{GP}_{24}$ & ME & T-DMd & T-OMd & $B$ & $P$ & $A$ & aNDFom & ADFom & ADL & NFC & TCT \\
\hline Maturation & -0.327 & $-0.497^{*}$ & $-0.496^{*}$ & $-0.498^{*}$ & -0.384 & $-0.606^{*}$ & $-0.540^{*}$ & $0.942^{* *}$ & $0.987^{* *}$ & $0.989^{* *}$ & $-0.927^{\star *}$ & $0.984^{* *}$ \\
\hline $\mathrm{GP}_{24}$ & 1 & $0.988^{* *}$ & $0.873^{* *}$ & $0.875^{* *}$ & $0.778^{* *}$ & $0.694^{*}$ & $0.743^{\star *}$ & $-0.615^{*}$ & $-0.467^{\star}$ & -0.370 & 0.073 & -0.173 \\
\hline$M E^{24}$ & & 1 & $0.899^{* *}$ & $0.900^{* *}$ & $0.815^{* *}$ & $0.756^{* *}$ & $0.792^{* *}$ & $-0.716^{\star *}$ & $-0.575^{*}$ & -0.477 & 0.176 & -0.294 \\
\hline T-DMd & & & 1 & $0.726^{* *}$ & $0.777^{* *}$ & $0.779^{* *}$ & $0.742^{* *}$ & $-0.727^{* *}$ & $-0.612^{*}$ & $-0.531^{*}$ & 0.265 & -0.362 \\
\hline T-OMd & & & & 1 & $0.658^{*}$ & $0.687^{*}$ & $0.697^{*}$ & $-0.718^{* *}$ & $-0.603^{*}$ & $-0.519^{*}$ & 0.254 & -0.364 \\
\hline B & & & & & 1 & $0.914^{* *}$ & $0.949^{* *}$ & $-0.605^{*}$ & $-0.566^{*}$ & -0.359 & 0.074 & -0.240 \\
\hline$P$ & & & & & & 1 & $0.968^{* *}$ & $-0.756^{* *}$ & $-0.671^{*}$ & $-0.596^{*}$ & $0.568^{*}$ & -0.496 \\
\hline A & & & & & & & 1 & $-0.713^{* *}$ & $-0.612^{*}$ & $-0.528^{*}$ & 0.284 & -0.420 \\
\hline aNDFom & & & & & & & & 1 & $0.979^{* *}$ & $0.942^{* *}$ & $-0.776^{* *}$ & $0.870^{* *}$ \\
\hline ADFom & & & & & & & & & 1 & $0.990^{* *}$ & $-0.888^{* *}$ & $0.949^{* *}$ \\
\hline ADL & & & & & & & & & & 1 & $-0.942^{* *}$ & $0.975^{\star *}$ \\
\hline NFC & & & & & & & & & & & 1 & $-0.972^{* *}$ \\
\hline
\end{tabular}

Maturation - plant maturation of Jerusalem artichoke herbage; $\mathrm{GP}_{24}, \mathrm{ME}, \mathrm{T}-\mathrm{DMd}$, T-OMd - see Table 5 ; $\mathrm{B}$ - butyric acid; $\mathrm{P}-$ propionic acid; A - acetic acid; aNDFom, ADFom, ADL, NFC, TCT - see Table $3 ;{ }^{* *}-P<0.01 ;{ }^{*}-P<0.05$

Table 8. Correlation coefficient ( $r$ ) relationship of chemical composition and some in vitro digestion parameters of Jerusalem artichoke herbage for ruminants

\begin{tabular}{|c|c|c|c|c|c|c|c|c|c|c|c|c|}
\hline Indices & $\mathrm{GP}_{24}$ & $\mathrm{ME}$ & T-DMd & T-OMd & $B$ & $P$ & $A$ & aNDFom & ADFom & $A D L$ & NFC & TCT \\
\hline Maturation & $-0.827^{* *}$ & $-0.570^{*}$ & $-0.698^{*}$ & $-0.545^{*}$ & $-0.744^{* *}$ & $-0.848^{* *}$ & $-0.864^{* *}$ & $0.942^{* *}$ & $0.987^{* *}$ & $0.989^{* *}$ & $-0.927^{* *}$ & $0.984^{* *}$ \\
\hline $\mathrm{GP}_{24}$ & 1 & 0.403 & $0.653^{*}$ & 0.444 & $0.819^{* *}$ & $0.887^{* *}$ & $0.941^{\text {** }}$ & $-0.786^{\star *}$ & $-0.838^{* *}$ & $-0.860^{* *}$ & $0.831^{* *}$ & $-0.823^{* *}$ \\
\hline $\mathrm{ME}$ & & 1 & 0.228 & 0.426 & 0.328 & 0.443 & 0.411 & $-0.649^{*}$ & $-0.571^{*}$ & -0.484 & 0.278 & -0.475 \\
\hline T-DMd & & & 1 & $0.555^{\star}$ & $0.648^{*}$ & $0.827^{* *}$ & $0.678^{*}$ & $-0.603^{*}$ & $-0.668^{*}$ & $-0.693^{*}$ & $0.707^{*}$ & $-0.718^{\star *}$ \\
\hline T-OMd & & & & 1 & $0.564^{*}$ & $0.508^{*}$ & $0.532^{*}$ & $-0.652^{*}$ & $-0.599^{*}$ & -0.552 & 0.386 & -0.466 \\
\hline B & & & & & 1 & $0.802^{* *}$ & $0.800^{* *}$ & $-0.722^{\star *}$ & $-0.760^{\text {** }}$ & $-0.774^{* *}$ & $0.733^{* *}$ & $-0.733^{* *}$ \\
\hline$P$ & & & & & & 1 & $0.875^{* *}$ & $-0.769^{\star *}$ & $-0.828^{* *}$ & $-0.845^{\star *}$ & $0.826^{* *}$ & $-0.852^{* *}$ \\
\hline A & & & & & & & 1 & $-0.878^{* *}$ & $-0.903^{* *}$ & $-0.909^{* *}$ & $0.828^{* *}$ & $-0.833^{* *}$ \\
\hline aNDFom & & & & & & & & 1 & $0.979^{* *}$ & $0.942^{* *}$ & $-0.776^{* *}$ & $0.870^{* *}$ \\
\hline ADFom & & & & & & & & & 1 & $0.990^{* *}$ & $-0.888^{* *}$ & $0.949^{* *}$ \\
\hline$A D L$ & & & & & & & & & & 1 & $-0.942^{* *}$ & $0.975^{\star *}$ \\
\hline NFC & & & & & & & & & & & 1 & $-0.972^{* *}$ \\
\hline
\end{tabular}

Maturation - plant maturation of Jerusalem artichoke herbage; $\mathrm{GP}_{24}, \mathrm{ME}, \mathrm{T}-\mathrm{DMd}$, T-OMd - see Table 5 ; $\mathrm{B}$ - butyric acid; $\mathrm{P}$ - propionic acid; A - acetic acid; aNDFom, ADFom, ADL, NFC, TCT - see Table $3 ;{ }^{* *}-P<0.01 ;{ }^{24}-P<0.05$

\section{Discussion}

Chemical composition of Jerusalem artichoke herbage. According to the obtained results, Jerusalem artichoke herbage can be described as forage with high or moderate protein content at the vegetative stage (NRC, 2001, 2007). In line with the present study, Stauffer et al. (1980) reported that the CP content in Jerusalem artichoke herbage was reduced from 18.0 to $6.2 \%$ depending on the progress of maturity stage. Besides, in the previous study it was found that the aerial biomass of Jerusalem artichoke at harvest time (September) contains $2.1-6.1 \%$ protein in DM (Gunnarsson et al., 2014). The CP content in lucerne herbage is $22.2 \%$ at the vegetative stage, $19.3 \%$ at the full flowering stage and $18.7 \%$ at the seeding stage according to NRC (2007). In the previous study, in which alterna- tive forage for arid lands was investigated, it was showed that the forage qualities of Atriplex patula and Plantago lanceolata herbages were similar to lucerne herbage; and CP content of these alternative forages at the early flowering stages was 14.64 and $10.74 \%$, respectively (Kara et al., 2016). In addition, CP content of Italian grass was $17.9 \%$ at the early vegetative stage and $10.3 \%$ at the end of the vegetative stage (NRC, 2007). The fact that the $C P$ content of Jerusalem artichoke herbage at vegetative stage was lower about $60 \%$ from that at early seed stage may be related to the high plant cell wall component with plant maturation.

The structural carbohydrate content (aNDFom, ADFom and lignin) of Jerusalem artichoke herbage was increasing along with plant maturation which involves increased lignifications and decreased proportion of leaves to stems (Van Soest et al., 1991), 
but NFC content was decreasing. The aNDFom and ADFom content of Jerusalem artichoke herbage at the vegetative stage were similar to the values reported for lucerne herbage at the vegetative stage (NRC, 2007). Gunnarsson et al. (2014) determined that cellulose content in aerial parts of Jerusalem artichoke at harvest time for tuber (September) was similar with that obtained in the present study, but lignin content varied from 2.1 to $6.1 \%$ in DM. In addition, the aNDFom and ADFom contents of Jerusalem artichoke herbage at the full flowering and early seeding stages were parallel to those of lucerne herbage at the same maturity stages (NRC, 2001, 2007; Kara et al., 2016). In addition, the contents of fibre substances in Jerusalem artichoke herbage obtained in this study are in agreement with the findings of Karsli and Bingöl (2009). The TCT content of Jerusalem artichoke herbage was increasing along with plant maturation, which may be related to increasing aNDFom and ADFom contents. According to current results, the TCT content of Jerusalem artichoke herbage was positively correlated with plant cell wall components (fibrous components). In the present study, ash content increased with plant maturation, which was in relation with results of Gunnarsson et al. (2014). The NFC contents of Jerusalem artichoke herbage were high for all maturity stages. These soluble carbohydrates were at recommended by NRC (2007) concentrations for the forage or diet of dairy and beef cattle.

The saponins are glycosides that occur in plants and are characterized by the ability to produce a soapy lather. They are derivatives of secondary plant metabolism, related to the plant defence system; they are either triterpenoid or steroid glycoside compounds in some saponin-containing plants, mainly legumes. The saponin-rich plants ( $>4 \%$ in DM) can be potentially used as feed additives in diets for ruminants to control ammonia and odour production. This is possible due to the effects of saponins on nitrogen metabolism (Cheeke, 2000). Feeding domestic animals forage with high levels of saponin can lead to toxicity. The saponin toxicity leads to photosensitization followed by liver and kidney degeneration in ruminants as well as gut problems like gastroenteritis and diarrhoea (Wina et al., 2005). The total saponin content of Jerusalem artichoke herbage decreased with plant maturation and was similar to the results of Lima et al. (2013) and was lower than those of saponin-rich plants, e.g., Quillaja saponaria (Rosaceae), Glycyrrhiza species (Leguminosae) and Yucca schidigera (Agavaceae) (Gracindo et al., 2014).
Despite the large variety of carotenoids in plants, there have been found approximately 10 types important for forages; the most important are lutein and $\beta$-carotene (Nozière et al., 2006). The lutein content of Jerusalem artichoke in the current study was slightly lower than that indicated for different forage by previous researchers (Calderón et al., 2006). The zeaxanthin content in the present study was similar with the values indicated for natural mountain grassland (in mid-June) (Calderón et al., 2006). In the present study, the $\beta$-carotene concentrations of Jerusalem artichoke herbage were satisfactory for vegetative, early flowering and full flowering stages, but its concentration was low at early seeding stage (Calderón et al., 2006). The high total carotenoid content of Jerusalem artichoke herbage at full flowering may be related to the yellow coloured flowers of this plant. In the present study, the lutein and $\beta$-carotene concentrations of Jerusalem artichoke herbage were higher (two or three times) than other carotenoids until the end of the full flowering stage. Reynoso et al. (2004) reported that the lutein and $\beta$-carotene concentrations of green forages are two- to three-fold higher than the same species in humid versus dry tropical areas. In the current experiment, the low $\beta$-carotene content in herbage at the early seeding stage may be associated with plant maturation, rapidly oxidized by light and the changing of leaf:stem ratio (Reynoso et al., 2004; Kane, 2009).

In vitro digestion parameters of Jerusalem artichoke herbage. In ruminants and horses, in vitro cumulative gas produced by Jerusalem artichoke herbage decreased along with plant maturation. The total gas production of Jerusalem artichoke herbage at the vegetative stage was adequate to obtain good quality forage. The total gas $\left(155-220 \mathrm{ml} \cdot \mathrm{g}^{-1} \mathrm{DM}\right)$ produced by Jerusalem artichoke herbage in ruminants was higher than that $\left(110-173 \mathrm{ml} \cdot \mathrm{g}^{-1} \mathrm{DM}\right)$ in horses at $24 \mathrm{~h}$. Frape (2004) stated that caecal microorganisms in horses tend to be less efficient in digestion of hay than ruminal microbes in ruminants. The fibre digestion difference has been attributed to the effects of differences in cellulolytic microbial species (Frape, 2004). However, total gas production of Jerusalem artichoke herbage at the early seeding stage was lower about $30 \%$ than that of vegetative stage in ruminants for $24 \mathrm{~h}$ incubation. This difference may be due to the in vitro methods used for different animal species and the digestive fluids. Generally, the in vitro gas production values of feed substances are connected with soluble carbohydrates (NFC) content (Kara et al., 2015, 2016; Kara, 2016). 
In both ruminants and horses, the T-DMd, T-OMd and ME values of Jerusalem artichoke herbage and the molar concentration of organic acids in fermentation fluid were decreasing with plant maturation, and these values may be related with changes in nutrient composition (NFC, CP, lignocellulose). For both animal species these digestion parameters were the highest at the vegetative stage, and the lowest at the early seeding stage. It is known that these in vitro digestion parameters in animal model are negatively affect by the increasing structural carbohydrates content and the rate of structural components (i.e. cellulose, hemicellulose and lignin) of aNDFom in the plant cells (Menke and Steingass, 1988; Kara et al., 2015). Besides, digestion rates of feed substances by different animal species are not the same due to enzymatic, microbial diversity, microorganisms number/count differences of their digestive tracts. This status may affect contents of inoculum used by the in vitro digestion studies. Differences of in vitro digestion rate in horses and ruminants may be due to the reasons mentioned above (Allen, 1997; NRC, 2001; Frape, 2004). In the present study, the structural carbohydrate contents of Jerusalem artichoke increased with maturation; and then these changes of structural carbohydrates could negatively affect digestion parameters. The fibrolytic enzymes being a part of complicated lingocellulose in plant cell wall can reduce the effectiveness of cellulose digestion. In addition, the ADL content was negatively correlated with in vitro gas production which is an important indicator of low digestion value in horses (Kara, 2016). In horse, in vitro gas production was positively correlated with T-DMd, T-OMd and ME values which was in agreement with previous in vitro digestion studies (Elghandour et al., 2015; Kara et al., 2015, 2016; Kholif et al., 2016). The estimated digestion values and ME values of Jerusalem artichoke herbage were satisfactory for horses forage according to NRC (2007).

In the current study, in vitro methane produced during Jerusalem artichoke herbage digestion in ruminants was at the expected level for forage (Kara et al., 2016). Methane production decreased with plant maturation, and this decrease may be related to the reduction in soluble carbohydrates composition and plant digestibility (Hook et al., 2010; Kara et al., 2015). The in vitro methane production in horses of this herbage harvested at different maturity stages was low or similar with the findings of Kholif et al. (2016) and Kara and Baytok (2017). These values demonstrated that the digestive tract of horses does not produce as much methane as that of ruminants.
The microbial profile of the horse caecum and right ventral colon and the rumen in ruminants are related to the diet composition (Julliand et al., 2001). The VFAs are one of the fermentation endproducts of feedstuffs in rumen and caecum. The amount of forage and concentrate fed also affects the VFA composition in the hindgut (horses) and the rumen (ruminants), with higher acetate concentrations of forage diet and higher propionate concentrations of high starch diet (Julliand et al., 2001; Kara et al., 2016). Even though the concentration of VFAs highly differs among diets, it generally ranges from 60 to $120 \mathrm{mmol} \cdot 1^{-1}$ of rumen fluid (Belanche et al., 2015; Kara et al., 2017). Murray et al. (2010) stated that the molar proportions of VFAs in the in vitro fermentation fluid with equine faecal inoculum changed from 71 to $90 \mathrm{mmol} \cdot \mathrm{l}^{-1}$ due to lucerne:sugar beet pulp ratio in diet. According to the results of the present study, the molar concentrations of the sum of VFAs $\left(90.49-81.19 \mathrm{mmol} \cdot 1^{-1}\right.$ vs 91.13-87.47 $\mathrm{mmol} \cdot 1^{-1}$ ) were similar for in vitro fermentation with faeces (for horses) and rumen inoculum (for ruminants). These results were similar with the in vitro study of Macheboeuf et al. (1997). The molar concentration of acetic, propionic and butyric acids and sum of VFAs in the in vitro fermentation with faeces and rumen inoculum were positively correlated with in vitro digestion values such as gas production, T-DMd and T-OMd. This is an indication that concentrations of organic acids change depending on the digestibility of the plant (Menke and Steingass, 1988; Kara et al., 2016). In the present study, the individual molar concentration of acetic, propionic and butyric acids for the in vitro fermentation with faeces and rumen inoculum were lower with increasing plant maturity stage, which may be associated with low NFC, high lignin and lignocellulose complexes content.

\section{Conclusions}

Jerusalem artichoke (Helianthus tuberosus L.) herbage, especially at the vegetative stage, has potential for use as good quality forage in terms of high/moderate nutrient composition and satisfactory digestion values in both horses and ruminants.

Nevertheless, the digestion values and the effect on performance of the aerial parts of Jerusalem artichoke for ruminants and horses should be investigated in more detail in in vivo studies. In addition, it is necessary to further investigate the Jerusalem artichoke during all its maturity stages in order to produce the forage of good quality. 


\section{Acknowledgement}

This study was based on the Master Thesis of Ahmet Çağrı Erşahince and was supported by Project No. TYL-2015-5844 granted by the Research Fund of Erciyes University, Kayseri (Turkey).

A part of this project (In vitro ruminal digestion values of Jerusalem artichoke herbage at different phenological stages) was presented at $12^{\text {th }}$ International Conference on Goats (25-30 September 2016), Turkey.

\section{References}

Allen M.S., 1997. Relation between fermentation acid production in the rumen and the requirement for physically effective fiber. J. Dairy Sci. 80, 1447-1462, https://doi.org/10.3168/jds. S0022-0302(97)76074-0

AOAC, 1990. Official Methods of Analysis of the Association of Official Analytical Chemists. 15 ${ }^{\text {th }}$ Edition. Arlington, VA (USA)

Altın T.B., Barak B., Altın B.N., 2012. Change in precipitation and temperature amounts over three decades in central Anatolia, Turkey. Atmos. Clim. Sci. 2, 107-125, https://doi.org/10.4236/ acs.2012.21013

Becker M., Nehring K. (Editors), 1969. Handbook of Feedstuffs (in German). Paul Parey Verlag. Hamburg and Berlin (Germany), pp. 159, 255, 340

Belanche A., de la Fuente G., Newbold C.J., 2015. Effect of progressive inoculation of fauna-free sheep with holotrich protozoa and total-fauna on rumen fermentation, microbial diversity and methane emissions. FEMS Microbiol. Ecol. 91, fiu026, https:// doi.org/10.1093/femsec/fiu026

Calderón F., Tornambé G., Martin B., Pradel P., Chauveau-Duriot B., Nozière P., 2006. Effects of mountain grassland maturity stage and grazing management on carotenoids in sward and cow's milk. Anim. Res. 55, 533-544, https://doi.org/10.1051/ animres:2006031

Cheeke P.R., 2000. Actual and potential applications of Yucca schidigera and Quillaja saponaria saponins in human and animal nutrition. J. Anim. Sci. 77 (E-Suppl.), 1-10, https://doi. org/10.2527/jas2000.00218812007700ES0009x

Crutzen P.J., Aselmann I., Seiler W., 1986. Methane production by domestic animals, wild ruminants, other herbivorous fauna, and humans. Tellus Ser. B - Chem. Phys. Meterol. 38, 271-284, https://doi.org/10.3402/tellusb.v38i3-4.15135

Elghandour M.M.M.Y., Kholif A.E., Bastida A.Z., Martínez D.L.P., Salem A.Z.M., 2015. In vitro gas production of five rations of different maize silage and concentrate ratios influenced by increasing levels of chemically characterized extract of Salix babylonica. Turk. J. Vet. Anim. Sci. 39, 186-194, https://doi. org/10.3906/vet-1408-62

Ellis J.L., Kebreab E., Odongo N.E., McBride B.W., Okine E.K., France J., 2007. Prediction of methane production from dairy and beef cattle. J. Dairy Sci. 90, 3456-3466, https://doi. org/10.3168/jds.2006-675

Frape D. (Editor), 2004. Frontmatter, in Equine Nutrition and Feeding.

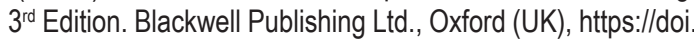
org/10.1002/9780470751053
Gracindo C.V., Louvandini H., Riet-Correa F., Barbosa-Ferreira M., de Castro M.B., 2014. Performance of sheep grazing in pastures of Brachiaria decumbens, Brachiaria brizantha, Panicum maximum, and Andropogon gayanus with different protodioscin concentrations. Trop. Anim. Health Prod. 46, 733-737, https://doi.org/10.1007/s11250-014-0556-y

Gunnarsson I.B., Svensson S.-E., Johansson E., Karakashev D., Angelidaki I., 2014. Potential of Jerusalem artichoke (Helianthus tuberosus L.) as a biorefinery crop. Indust. Crop. Prod. 56, 231-240, https://doi.org/10.1016/j.indcrop.2014.03.010

Helmi Z., Azzam K.M.A., Tsymbalista Y., Ghazleh R.A., Shaibah H., Aboul-Enein H., 2014. Analysis of essential oil in Jerusalem artichoke (Helianthus tuberosus L.) leaves and tubers by gas chromatography-mass spectrometry. Adv. Pharm. Bull. 4 (Suppl. 2), 521-526, https://doi.org/10.5681/apb.2014.077

Hook S.E., Wright A.-D.G., McBride B.W., 2010. Methanogens: methane producers of the rumen and mitigation strategies. Archaea 2010, 945785, https://doi.org/10.1155/2010/945785

Intergovernmental Panel on Climate Change (IPCC), 2014. Summary for policymakers. In: Climate Change 2014: Mitigation of Climate Change. Contribution of Working Group III to the Fifth Assessment Report of the Intergovernmental Panel on Climate Change. Cambridge University Press, Cambridge (UK) and New York, NY (USA)

Julliand V., de Fombelle A., Drogoul C., Jacotot E., 2001. Feeding and microbial disorders in horses: Part 3 - Effects of three hay:grain ratios on microbial profile and activities. J. Equine Vet. Sci. 21, 543-546, https://doi.org/10.1016/S07370806(01)70159-1

Kamalak A., Canbolat O., Sahin M., Gurbuz Y., Ozkan C.O., 2005. The effect of polyethylene glycol (PEG 8000) supplementation on in vitro gas production kinetics of leaves from tannin containing trees. South Afr. J. Anim. Sci. 35, 229-237, https://doi. org/10.4314/sajas.v35i4.3964

Kane E.D., 2009. Beta-carotene: an essential nutrient for horses? Adv. Equine Nutr. 4, 51-60

Kara K., 2015. In vitro methane production and quality of corn silage treated with maleic acid. Ital. J. Anim. Sci. 14, 3994, https:// doi.org/10.4081/ijas.2015.3994

Kara K., 2016. Effect of dietary fibre and condensed tannins concentration from various fibrous feedstuffs on in vitro gas production kinetics with rabbit faecal inoculum. J. Anim. Feed Sci. 25, 266-272, https://doi.org/10.22358/jafs/65563/2016

Kara K., Aktuğ E., Özkaya S., 2016. Ruminal digestibility, microbial count, volatile fatty acids and gas kinetics of alternative forage sources for arid and semi-arid areas as in vitro. Ital. J. Anim. Sci. 15, 673-680, https://doi.org/10.1080/182805 1X.2016.1249420

Kara K., Baytok E., 2017. Effect of different levels of psyllium supplementation to horse diet on in vitro fermentation parameters and methane emission. J. Fac. Vet. Med. Istanbul Univ. 43, 12-18, https://doi.org/10.16988/iuvfd.255208

Kara K., Güçlü B.K., Baytok E., 2015. Comparison of nutrient composition and anti-methanogenic properties of different Rosaceae species. J. Anim. Feed Sci. 24, 308-314, https:// doi.org/10.22358/jafs/65613/2015

Kara K., Özkaya S., Erbaş S., Baytok E., 2017. Effect of dietary formic acid on the in vitro ruminal fermentation parameters of barleybased concentrated mix feed of beef cattle. J. Appl. Anim. Res. https://doi.org/10.1080/09712119.2017.1284073

Karsli M.A., Bingöl N.T., 2009. The determination of planting density on herbage yield and silage quality of Jerusalem artichoke (Helianthus tuberosus L.) green mass (in Turkish). Kafkas Univ. Vet. Fak. Derg. 15, 581-586 
Kays S.J., Nottingham S.F., 2007. Classification, identification, and distribution. In: Biology and Chemistry of Jerusalem Artichoke: Helianthus tuberosus L. CRC Press. Boca Raton, FL (USA), pp. 29-34, https://doi.org/10.1201/9781420044966.ch3

Kholif A.E., Baza-García L.A., Elghandour M.M.Y., Salem A.Z.M., Barbabosa A., Dominguez-Vara I.A., Sanchez-Torres J.E., 2016. In vitro assessment of fecal inocula from horses fed on high-fiber diets with fibrolytic enzymes addition on gas, methane, and carbon dioxide productions as indicators of hindgut activity. J. Equine Vet. Sci. 39, 44-50, https://doi. org/10.1016/j.jevs.2015.11.006

Konopiński T., Bormann J. (Editors), 1937. Domestic Animal Nutrition (in Polish). Wydawnictwo Wielkopolskiej Izby Rolniczej. Poznań (Poland), pp. 155-156

Lima F.G., Haraguchi M., Pfister J.A., Guimaraes V.Y., Andrade D.D.F., Ribeiro C.S., Costa G.L., Araujo A.L.L., Fioravanti M.C.S., 2013. Weather and plant age affect the levels of steroidal saponin and Pithomyces chartarum spores in Brachiaria grass. Int. J. Poisonous Plant Res. 2, 45-53

Macheboeuf D., Jestin M., Chenost M., 1997. Comparison of in vitro digestion of hays with horse caecal and sheep rumen fluids. Reprod. Nutr. Dev. 37 (Suppl. 1), 57-58, https://doi. org/10.1051/rnd:19970738

Makkar H.P.S., Blümmel M., Becker K., 1995. Formation of complexes between polyvinyl pyrrolidones or polyethylene glycols and their implication in gas production and true digestibility in vitro techniques. Br. J. Nutr. 73, 897-913, https://doi.org/10.1079/ BJN19950095

Menke K.H., Steingass H., 1988. Estimation of the energetic feed value obtained from chemical analysis and in vitro gas production using rumen fluid. Anim. Res. Develop. 28, 7-55

Murray J.-A.M.D., Bice R.K.T., Moore-Colyer M.J.S., 2010. The effect of particle size on the in vitro fermentation of different ratios of high-temperature dried lucerne and sugar beet pulp incubated with equine faecal inocula. Anim. Feed Sci. Technol. 162, 47-57, https://doi.org/10.1016/j.anifeedsci.2010.09.001

Nozière P., Graulet B., Lucas A., Martin B., Grolier P., Doreau M., 2006. Carotenoids for ruminants: From forages to dairy products. Anim. Feed Sci. Technol. 131, 418-450, https://doi. org/10.1016/j.anifeedsci.2006.06.018

NRC, 2001. Nutrient Requirements of Dairy Cattle. $7^{\text {th }}$ Revised Edition. National Academy Press. Washington, DC (USA), https://doi. org/10.17226/9825

NRC, 2007. Nutrient Requirements of Horses. $6^{\text {th }}$ Revised Edition. National Academy Press, Washington, DC (USA), https://doi. org/10.17226/11653

Razmkhah M., Rezaei J., Fazaeli H., 2017. Use of Jerusalem artichoke tops silage to replace corn silage in sheep diet. Anim. Feed Sci. Technol. 228, 168-177, https://doi.org/10.1016/j. anifeedsci.2017.04.019
Reynoso C.R., Mora O., Nieves V., Shimada A., de Mejía E.G., 2004. $\beta$-carotene and lutein in forage and bovine adipose tissue in two tropical regions of Mexico. Anim. Feed Sci. Technol. 113, 183-190, https://doi.org/10.1016/j.anifeedsci.2003.11.007

Rodriguez-Amaya D.B., 1999. A Guide to Carotenoid Analysis in Foods. International Life Sciences Institute Press. Washington, DC (USA)

Shaver R., 1997. Nutritional risk factors in the etiology of left displaced abomasum in dairy cows: a review. J. Dairy Sci. 80, 24492453, https://doi.org/10.3168/jds.S0022-0302(97)76197-6

Stauffer M.D., Chubey B.B., Dorrell D.G., 1980. Growth, yield and compositional characteristics of Jerusalem artichoke as it relates to biomass production. Am. Chem. Soc. Div. Fuel. Chem. 25, 193-203

Sunvold G.D., Hussein H.S., Fahey G.C. Jr, Merchen N.R., Reinhart G.A., 1995. In vitro fermentation of cellulose, beet pulp, citrus pulp, and citrus pectin using fecal inoculum from cats, dogs, horses, humans, and pigs and ruminal fluid from cattle. J. Anim. Sci. 73, 3639-3648, https://doi. org/10.2527/1995.73123639x

Sweeney C.R., 2012. In vivo and in vitro digestibility of a complete pelleted feed in horses. Master of Science Thesis. The Faculty of California Polytechnic State University. San Luis Obispo, CA (USA), https://doi.org/10.15368/theses.2012.167

Szpunar-Krok E., Bobrecka-Jamro D., Grochowska S., Buczek J., 2016. Yield of the aboveground parts and tubers of Jerusalem artichoke (Helianthus tuberosus L.) depending on plant density. Acta Sci. Pol. Agricultura 15(3), 69-78

Wina E., Muetzel S., Becker K., 2005. The impact of saponins or saponin-containing plant materials on ruminant productions: A review. J. Agric. Food Chem. 53, 8093-8105, https://doi. org/10.1021/jf048053d

Vador N., Vador B., Hole R., 2012. Simple spectrophotometric methods for standardizing ayurvedic formulation. Indian J. Pharm. Sci. 74, 161-163, https://doi.org/10.4103/0250-474X.103852

Van Soest P.J., Robertson J.B., Lewis B.A., 1991. Methods for dietary fiber, neutral detergent fiber and nonstarch polysaccharides in relation to animal nutrition. J. Dairy Sci. 74, 3583-3597, https://doi.org/10.3168/jds.S0022-0302(91)78551-2

Yang L., He S.Q., Corscadden K., Udenigwe C.C., 2015. The prospects of Jerusalem artichoke in functional food ingredients and bioenergy production. Biotechnol. Rep. 5, 77-88, https://doi. org/10.1016/j.btre.2014.12.004

Yusuf R.O., Noor Z.Z., Abba A.H., Hassan M.A.A., Din M.F.M., 2012. Greenhouse gas emissions: quantifying methane emissions from livestock. Am. J. Eng. Appl. Sci. 5, 1-8, https://doi. org/10.3844/ajeassp.2012.1.8 